\title{
0-6 Yaş Grubu Çocuğu Olan Annelerin Ev Kazalarına Yönelik Güvenlik Önlemlerini Tanılama Düzeyleri Ve Annelere Verilen Ev Kazalarına Yönelik Eğitimin Etkisi
}

\section{Diagnostic levels of Mothers having Children between the age of 0-6 years about Taking Precautions against Home Accidents and the Effects of Training on Home Accidents}

Selen ÖZAKAR AKÇA ${ }^{1}$, Tuğba ÇANKAYA ${ }^{2}$ Zehra AYDIN $^{1}$

1 Hitit Üniversitesi Sağlık Yüksekokulu. Samsun Cad., 19000, Çorum

2 Hitit Üniversitesi Erol Olçok Eğitim ve Araştırma Hastanesi, Dahiliye Kliniği

\section{öz}

Amaç: 0-6 yaş arası çocukların karşılaştıkları kazalar, önemli sağlık sorunlarındandır. Temel olarak çocukları kazalardan korumak yetişkinlerin sorumluluğundadır. Bu çalışma ile 0-6 yaş grubu çocuğu olan annelerin ev kazalarından korumaya yönelik güvenlik önlemlerine ilişkin tutumlarını tanılamak ve bu konu ile ilgili verilen eğitimin annelerin bilgi düzeyleri üzerine etkisini belirlemek amaçlanmıştır.

Gereç ve Yöntem: Araştırma Çorum ilinde 20.11.1403.03.15 tarihleri arasında yapılmış, anaokuluna devam eden 0-6 yaş arası çocuğu olan, çalışmaya katılmaya istekli 200 anne araştırmanın örneklemini oluşturmuştur. Araştırma verileri Soru Formu, Sıfır-Altı Yaş Çocuklarda Annelerin Ev Kazalarına Yönelik Güvenlik Önlemlerini Tanılama Ölçeği uygulanarak toplanmıştır.

Bulgular: Araştırmaya 0-6 yaş grubu çocuğu olan 200 anne katılmış olup, annelerin yaş ortalaması $33.11 \pm 5.22$ 'dir. Annelerin gelir seviyesi, aile tipi ve çocuğun önceden kaza geçirme durumu ile ölçekten alınan ortalama puanlar arasında istatistiksel olarak anlamlı bir farklılık olduğu belirlenmiştir $(p<0.01)$. Annelerin Eğitim Öncesi (EÖ) ölçek puan ortalaması 70.95 \pm 13.41 iken Eğitim sonrası (ES) ölçek puan ortalaması $151.72 \pm 61.67$ 'dir. EÖ ve ES ölçek puan ortalamaları arasındaki farkın istatistiksel olarak anlamlı olduğu $(p<0.001)$ belirlenmiştir.

Sonuç: Çocukları kaza geçiren annelerin bu kazalar sonucunda deneyim kazandıkları ve annelere verilen ev kazalarından korunmaya yönelik eğitimin, annelerin bu konudaki bilgi düzeylerinde artışa neden olduğu belirlenmiştir. Annelerin ev kazalarını önleyebilecekleri konusunda farkındalıklarının artırılması önerilmektedir.

Anahtar Kelimeler: 0-6 yaş çocuk, anne, eğitim, ev kazaları

Corresponding Author: Yrd. Doç. Dr. Selen ÖZAKAR AKÇA

Address: Hitit Üniversitesi Sağlık Yüksekokulu/ ÇORUM-Türkiye

E-mail: selenozakar@hotmail.com, selenozakar@gmail.com,

selenozakar@hitit.edu.tr

Başvuru Tarihi/Received:

19-05-2016

Kabul Tarihi/Accepted:

13-06-2016

\section{ABSTRACT}

Objective: Accidents encountered by 0-6 years old children are one of the major health problems. Basically it is the responsibility of adults to protect children from accidents. This study was designed and carried out to determine the attitude of mothers with 0-6 years old children towards safety measures taken against home accidents and the effects of home accidents training on mothers' knowledge level.

Method: The study has been carried out in the city of Çorum in Turkey between the dates of 20.11.14-03.03.15. 200 mothers who had kindergarten children in the age group of 0-6 and who agreed to take part in the study were included and constituted the study sample. The data of the study was collected by using Questionnaire Survey Data and applying the Scale for Identification of the Safety Measures Taken by Mothers to Prevent Home Accidents of Children in the 0-6 age group.

Results: 200 mothers who have children in the age of 0-6 participated in the study and had an average age of $33.11 \pm 5.22$. It was determined that there is a statistically significant difference between the income level of mothers, family type, accident status of children and the obtained point average from the scale $(p<0.01)$. While the scale point average before training (BT) was $70.95 \pm 13.41$ the point average after training (AT) has been identified as $151.72 \pm 61.67$. It was determined that the difference of point averages between BT and AT is statistically significant ( $p$ $<0.001$ ).

Conclusion: The training for the prevention of home accidents provided to mothers has led to an increase in knowledge on this topic and it has been determined that mothers whose children had an accident before have gained experience as a result of those accidents. Therefore it is highly recommended to increase the awareness of mothers on the prevention of home accidents.

Keywords: $0-6$ years old children, mother, training, home accidents 


\section{GiRiş:}

GiRiş:

Kaza; Dünya Sağlık Örgütü (DSÖ) tarafından bireyin iradesi dışında süratle etki yapan; dış bir güç tarafından açığa çıkan zihinsel ve vücuda ait bir hasar ile sonuçlanan bir olay olarak tanımlanmaktadır (1). 0-6 yaş arası çocukların karşılaştıkları kazalar, önemli sağlık sorunlarındandır $(2,3)$. Çünkü kazalar çocuklara fiziksel, psikolojik ve sosyal yönden etki ederek onun dengesini bozmakta bunun sonucunda da hastalık oluşturmaktadır. Bu nedenle kazalar, üzerinde durulması gereken önemli bir toplum sağlığı sorunudur $(3,4)$. Yapılan çalışmalarda çocukların hastalık sorunları ile tüm ülkelerin yakından ilgilendiği böylece çocukların hastalıklardan dolayı ölüm oranının azaldığı görülmektedir. Fakat kazaların görülme sıklığının ve ölüm oranının önemini koruması, çocukluk çağındaki kazalara gereken önemin verilmediğini ve kazalarla ilgili çalışmaların sınırlı kaldığını düşündürmektedir $(4,5)$.

Ev kazaları sıklığı, ülkeler ve yaş gruplarına göre değişmekle birlikte çocukluk çağı kazalarının \% 25'ni oluşturmaktadır (6). DSÖ’ne göre Ekonomik Kalkınma ve Iş̧birliği Örgütü'ne (OECD) üye ülkelerde her gün 2000'den fazla çocuk kazalar nedeniyle ölmekte, çok sayıda çocuk kazaların fiziksel, psikolojik ve sosyal etkisine maruz kalmaktadır (7). Türkiye'de ise tüm kazaların \% 18-25'ni çocukluk çağı ev kazalarının oluşturduğu bildirilmiştir $(6,8)$.

Sıfır-6 yaş grubundaki çocuklar tehlikelerin bilincinde olmamaları, çevresel risklere açık olmaları, bulma ve öğrenme konularında meraklı olmaları ve kazalardan kendilerini koruyabilecek gelişim özelliklerine sahip olmamaları nedeniyle kazalarla karşı karşıya kalmaktadırlar (2,9-11). Bu nedenle çocuklara güvenli bir çevre oluşturulması ve kazalardan korunması için bir yetişkin gereklidir. Temel olarak çocukları kazalardan korumak yetişkinlerin sorumluluğundadır (11-13). Kazaların \% 87'sinin önlenebilir ve annelerin çocuğun yakınındaki birey olduğu göz önüne alınırsa; çocukları kazalardan korumak amacıyla yapılacak olan güvenlik önlemleri üzerine annelere verilen eğitimin kazaları önlemede önemli bir role sahip olduğu görülmektedir $(3,11,14)$.

Günümüzde sağlık ekibinin önemli bir üyesi olan hemşirelerin; hasta bakımından, sağlığı koruma ve geliştirmeye yönelik birçok görev ve sorumlulukları bulunmaktadır. Çocukluk çağında önemli mortalite ve morbiditeye neden olan kazaların önlenmesi ve azaltılmasında ailelere verilecek eğitimde hemşirenin sorumluluğu son derece önemlidir $(10,11,15-17)$. Aileleri kazalar konusunda eğitme görevini, danışmanlık ve eğitici rolü olan hemşirelerin yerine getirmesi önerilmektedir $\quad(15,17)$. Çocuklardaki yaralanma oranını azaltmada annelerin ev kazalarındaki güvenlik önlemleri konusunda bilgilenmesinin son derece önemli olduğu vurgulanmaktadır. Bu doğrultuda; kazaların önlenmesi, ev içerisinde yapılacak basit düzenlemelerle ve çocukların sürekli yanında bulunan annelere verilecek düzenli eğitimlerle sağlanabilmesi düşünüldüğünde bu önleme programlarının uygulanması çocukların yaşamlarını sağlıklı bir şekilde devam ettirmelerini sağlayacaktır $(3,8,16,18)$.

Çocuk bakımından sorumlu bireylerin eğitilmesi ve motivasyonu göz önüne alındığında; sunulan bu araştırma ile 0-6 yaş grubu çocuğu olan annelerin ev kazalarından korumaya yönelik güvenlik önlemlerine ilişkin tutumlarını tanılamak ve bu konu ile ilgili verilen eğitimin annelerin bilgi düzeyleri üzerine etkisini belirlemek amaçlanmıştır.

\section{GEREÇ VE YÖNTEM}

Çalışmanın Türkiye'de Çorum ilinde anaokuluna (Buharaevler, Karşıyaka, Nasrettin Hoca, Ulukavak, Mimar Sinan, Sevgi, ikbalevler, Ipekli bağlar, Mehmet Akif Ersoy) devam eden 0-6 yaş arası çocuğu olan tüm annelerde yarı deneysel olarak yapılması planlanmıştır. Araştırma 20 Aralık 2014 ve 03 Mart 2015 tarihleri arasında gerçekleştirilmiştir. Araştırmada örneklem yöntemi seçimine gidilmemiş olup, çalışmanın yapıldığı tarihler arasında anaokulunda ulaşılabilen 0-6 yaş grubunda çocuğu olan, iletişim engeli olmayan, araştırmaya katılmaya gönüllü ve okur-yazar olan anneler araştırmaya alınmıştır. Yapılan güç analizi sonucunda 0.05 anlamlılık düzeyi ve \% 85 güç için örneklem büyüklüğü 130 kişi olarak belirlenmiştir. Hesaplanan örneklem sayısının değişkenler arasındaki 
bağın ortaya konulmasında daha güçlü olması amacıyla toplam 200 annenin örneklemi oluşturmasına karar verilmiştir.

Araştırmaya başlamadan önce ilgili kurumlardan izin (30.03.2013/393574) ve Ankara Numune Eğitim ve Araştırma Hastanesi Etik Kurulu'ndan etik kurul onayı (18.08.2014/E-14-274) alınmıştır. Ayrıca araştırmaya katılmaya gönüllü olan annelere araştırmanın amacı ile ilgili bilgi verilerek yazıı onam alınmıştır.

Araştırmanın bağımsız değişkenleri; annelerin bazı tanıtıcı özellikleri iken, bağımlı değişkenleri; annelerin 0-6 Yaş Çocuklarda Annelerin Ev Kazalarına Yönelik Güvenlik Önlemlerini Tanılama Ölçeği”nden aldıkları puanlardır.

Araştırmanın verileri anket formu ve "SıfırAltı Yaş Çocuklarda Annelerin Ev Kazalarına Yönelik Güvenlik Önlemlerini Tanılama Ölçeği" uygulanarak toplanmıştır.

Anket Formu; uzman görüşleri doğrultusunda araştırmacılar tarafından geliştirilmiş olup, bu formda 0-6 yaş grubu çocuğu olan annelerin bazı tanıtıcı özelliklerini (yaşı, eğitim durumu, ailenin ekonomik durumu, evde yaşayan çocuk sayısı, aile tipi, çocuğun önceden ev kazası geçirme durumu, vs) belirlemeye yönelik sorular bulunmaktadır.

Sıfır-Altı Yaş Çocuklarda Annelerin Ev Kazalarına Yönelik Güvenlik Önlemlerini Tanılama Ölçeği; Çınar ve Görak (19) tarafından 0-6 yaş çocuğu olan annelerin çocuklarını ev kazalarından korumaya yönelik güvenlik önlemlerine ilişkin tutumlarını tanılamak amacıyla geliştirilmiştir. Ölçeğin Cronbach Alfa iç tutarlılık katsayısı 0.82'dir. Bu ölçekte 34 olumlu, 6 olumsuz ifade içeren toplam 40 maddeden oluşan 5 'li Likert tipi ölçekte her bir maddeye 1-5 arasında puan verilmiştir. Puanlamada; "her zaman: 5 puan, çoğu zaman: 4 puan, bazen: 3 puan, nadiren: 2 puan, hiçbir zaman: 1 puan" olarak belirlenmiştir. 6, 9, 23, 26, 30, 40'ıncı maddeler olumsuz ifade içeren maddeler olup, negatif ifade içeren maddelerin puanları tersine çevrilerek kullanılmaktadır. Ölçeğin en düşük puanı 40, en yüksek puanı 200 olup, en yüksek puan annelerin çocuğunu ev kazalarından korumaya yönelik önlemleri en üst düzeyde aldığını gösterir $(2,3,11,19)$.
Anket formu ve "Sıfır-Altı Yaş Çocuklarda Annelerin Ev Kazalarına Yönelik Güvenlik Önlemlerini Tanılama Ölçeği"nin ön uygulaması 10 anneye uygulanmış, alınan yanıtlar doğrultusunda gerekli düzeltmeler yapılmış ve veri toplama formlarına son şekli verilmiştir. Formun ön uygulamasını yapan ve çalışmanın yapıldığı tarihlerde anaokulunda olmayan anneler çalışma dışı bırakılmıştır. Araştırma verileri, 0-6 yaş grubu çocuğu olan anneler tarafından, araştırmacıların gözetiminde eğitim öncesi (EÖ) ve eğitimden bir ay sonrası (ES) olmak üzere toplam 15 dakikalık bir süre içinde doldurmaları sonucu elde edilmiştir.

Ev Kazalarından Korunmaya Yönelik Eğitim; görsel sunu ve annelere dağıtılan broşürlerle araştırmacılar tarafından gerçekleştirilmiştir.

Görsel sunu; literatür doğrultusunda $(2,3,10,15,18-21)$ hazırlanmış olup, ortalama $45 \mathrm{dk}$ sürmüştür. Görsel eğitimin konu başlıkları; "Kaza nedir? Ev kazası nedir? Kaza oluşumunda yaşanılan yere ait etmenler ve alınabilecek önlemler nelerdir? 0-6 yaş arasında en fazla karşılaşılan kazalar ve alınması gereken önlemler nelerdir?" sorularının cevaplarını içermiştir.

Annelere dağıtılan broşürler ise; araştırmacı tarafından literatür bilgileri doğrultusunda "Ev Kazalarından Korunma" bilgilerini içerecek şekilde hazırlanmış olup, uzman görüşlerine sunulmuştur. Gerekli düzenlemelerden sonra broşürler eğitim esnasında annelere dağıtılmıştır. Bu şekilde görsel sunu ile verilen eğitimin broşürlerle desteklenmesi sağlanmıştır. Annelere verilen, "Ev Kazalarından Korunmaya Yönelik Eğitim" 20 kişilik 10 grup şeklinde gerçekleştirilmiş, eğitimlerin anlatım, soru-cevap ve tartışma şeklinde interaktif olması sağlanmıştır.

Araştırma verilerinin değerlendirilmesinde SPSS (Version 22.0, SPSS Inc., Chicago, IL, USA; lisans, Hitit Üniversitesi) paket programı kullanılmıştır. Annelerin bazı tanıtıcı özelliklerinde sürekli değişkenler ortalama \pm standart sapma, kategorik değişkenler sayı ve yüzde olarak sunulmuştur. Anne özelliklerine göre ölçek puanlarının ortalama karşılaştırmalarında bağımsız gruplarda iki örneklem için bağımsız örneklem $t$ testi (Independent sample $t$ test) normal dağılmayan veriler için Mann Whitney $U$ testi, 
ikiden fazla grup karşılaştırmaları için ANOVA, normal dağılmayan veriler için Kruskal-Wallis testi kullanılmıştır. Varyans analizi sonrasında farklılığın hangi gruplardan kaynaklandığını belirlemek için Post-hoc testleri (Bonferroni) yapılmıştır. "Sıfır-Altı Yaş Çocuklarda Annelerin Ev Kazalarına Yönelik Güvenlik Önlemlerini Tanılama Ölçeği"nden elde edilen verilerin değerlendirilmesinde bağımlı gruplar için iki eş arasındaki farkın önemlilik testi (Paired sample t-test) kullanılmıştır. İstatistiki anlamlılık düzeyi için $p<0.05$ olarak kabul edilmiştir.

\section{BULGULAR}

Araştırmaya toplam 200 anne katılmış olup, annelerin yaş ortalaması $33.11 \pm 5.22^{\prime}$ dir. Çalışmaya katılan annelerin \% 61'i ilköğretim mezunu olup, annelerin bazı tanıtıcı özelliklerine göre dağılımları Tablo 1'de verilmiştir.

Tablo 1. Annelerin Bazı Tanıtıcı Özelliklerinin Dağılımı $(\mathrm{N}=\mathbf{2 0 0})$

\begin{tabular}{ccc} 
& $(\mathbf{N = 2 0 0})$ & \\
\hline Özellikler & $\mathbf{n}$ & \\
& & \\
& & \\
Anne Yaşı & & 33.0 \\
$21-30$ & 66 & 39.5 \\
$31-40$ & 79 & 27.5 \\
$41-50$ & 55 & \\
& & 61.0 \\
Annenin Ĕgitim Durumu & & 23.0 \\
İlköğretim mezunu & 122 & 16.0 \\
Lise mezunu & 46 & \\
Yüksek okul mezunu & 32 &
\end{tabular}

\begin{tabular}{ccc} 
Aile Gelir Seviyesi & & \\
Gelir-Gidere az & 138 & 69.0 \\
Gelir-Giderden eşit & 46 & 23.0 \\
Gelir-Giderden çok & 16 & 8.0 \\
\hline & & \\
Evdeki Çocuk Sayısı & & \\
Bir & 50 & 25.0 \\
İki & 98 & 49.0 \\
$\leq \ddot{\text { U̧ }}$ & 52 & 26.0 \\
\hline
\end{tabular}

\begin{tabular}{ccc} 
Aile Tipi & & \\
Çekirdek aile & 170 & 85.0 \\
Geniş aile & 20 & 10.0 \\
Diğer & 10 & 5.0 \\
\hline
\end{tabular}

\begin{tabular}{ccc}
$\begin{array}{c}\text { Cocuğun Ev Kazası } \\
\text { Geçirme Durumu }\end{array}$ & & \\
Evet & 31 & 15.5 \\
Hayır & 169 & 84.5 \\
\hline Anne Yaş Ortalaması & Ort $=33.11$ & $\mathrm{SS} \pm 5.21$ \\
\hline
\end{tabular}

Araştırmaya katılan annelerin ölçekten aldıkları toplam puan ortalaması $70.95 \pm 13.41^{\prime}$ dir.

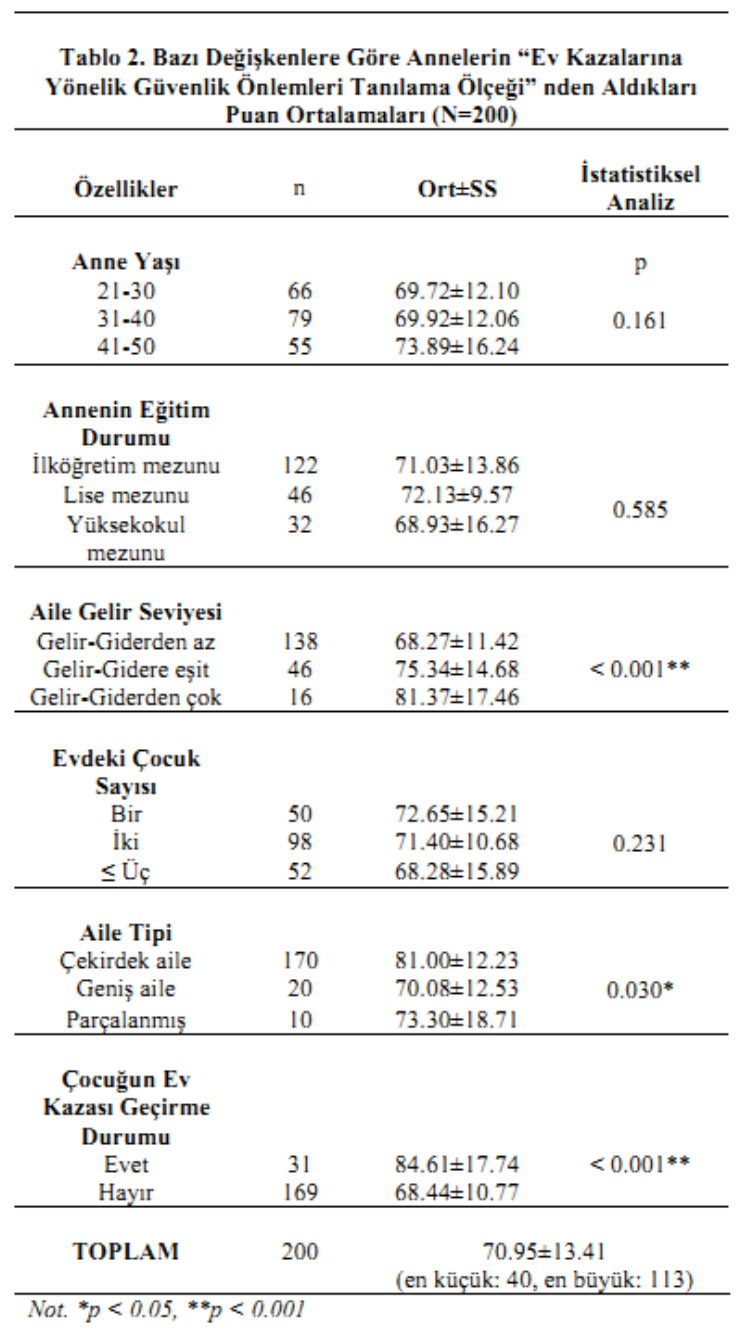

Tablo 2'de annelerin bazı tanıtıcı özelliklerine göre "SIfır-Altı Yaş Çocuklarda Annelerin Ev Kazalarına Yönelik Güvenlik Önlemlerini Tanılama Ölçeği”nden aldıkları puan ortalamaları arasındaki fark incelendiğinde; annelerin gelir seviyesi, aile tipi ve çocuğun önceden kaza geçirme durumu ile ölçekten alınan ortalama puanlar arasında istatistiksel olarak anlamlı bir farklılık olduğu belirlenmiştir (sırasıyla; $p<0.001 ; p=0.030 ; p<0.001$ ). Annelerin gelir seviyesi ile ev kazalarına yönelik ölçek puanlarında istatistiksel açıdan önemli fark, $(p<0.001)$ geliri giderinden az olanlar ile geliri giderinden eşit ve fazla olan gruplar arasında olduğu belirlenmiştir. Araştırmaya katılan annelerin aile tipi ile ölçekten aldıkları puan ortalamaları arasındaki istatistiksel açıdan anlamlı farkın çekirdek aile yapısına sahip olanlar ile geniş aile yapısına 
sahip olan gruplar arasında olduğu gözlenmiştir ( $p=0.030)$. Annelerin bazı değişkenlerine göre "Sıfır-Altı Yaş Grubu Çocuğu Olan Annelerin Ev Kazalarına Yönelik Güvenlik Önlemlerini Tanılama Ölçeği"nden aldıkları puan ortalamalarının dağılımları Tablo 2'de yer almaktadır.

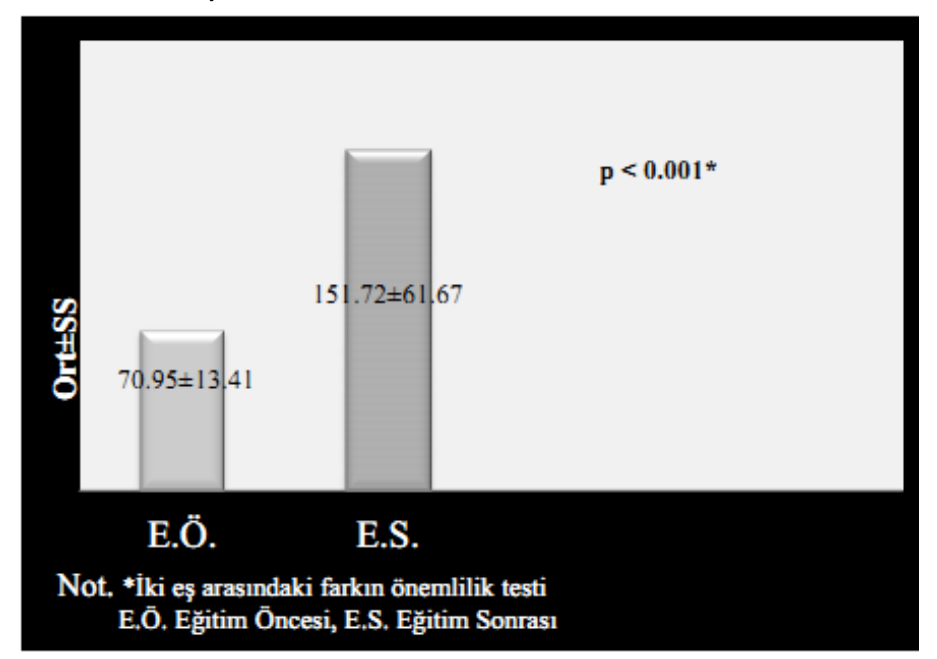

Şekil 1. Annelerin "Sıfır-Altı Yaş Çocuklarda Annenin EV Kazalarına Yönelik Güvenlik Önlemleri Tanılama Ölçeği" Puan Ortalamalarının Karşılaştırılması $(N=200)$

\begin{tabular}{cllr}
\multicolumn{1}{c}{ Annelerin } & "Sıfır-Altı & Yaş Çocuklarda \\
Annelerin Ev & Kazalarına & Yönelik Güvenlik \\
Önlemlerini & Tanılama Ölçeği" & puan
\end{tabular}
ortalamaları karşılaştırılmasında; annelerin EÖ ölçek puan ortalaması $70.95 \pm 13.41$ (en küçük: 40, en büyük: 113) iken ES ölçek puan ortalaması 151.72 \pm 61.67 (en küçük: 53, en büyük: 200)'dir. EÖ ve ES ölçek puan ortalamaları arasındaki farkın istatistiksel olarak anlamlı olduğu $(p<0.001)$ belirlenmiştir (Şekil 1).

\section{TARTIŞMA}

Ev kazaları sık görülmeleri, ölüm ve sakatlıklara yol açmaları nedeniyle önemli bir halk sağlığı sorunu olarak gündemini korumaktadır. Ev kazalarının önlenmesinde; kaza olgusunun farklı boyutlarda nedenleri ve sonuçlarının irdelenmesi, ailelerin ve toplumun bu konuda bilinçlendirilmesi, çocukların ve ebeveynlerin yaşam düzeylerinin iyileştirmesi önem kazanmaktadır. Önlenebilir kazalarla ilgili ailelerin çocukları için tüm tehlikelerden haberdar olmaları beklenemez. Ancak ailelere eğitim verilerek nerede ne yapmaları gerektiği öğretilebilir ve farkındalıkları artırılabilir $(3,15,22)$. Ev kazaları önlemede eğitimin anahtar bir yaklaşım olduğu bildirilmektedir $(3,11)$.

Türkiye İstatistik Kurumu (2014) verilerine göre ülkemizde ilkokul mezunu oranı \% 28'dir (23). Çalışmamızda çocukların annelerininin \% 61'inin ilköğretim mezunu ve \% 69'unun gelirinin-giderinden az olduğu belirlenmiştir (Tablo 1). Çalışmamızda ilköğretim mezunu anne oranının yüksek olması örneklemi oluşturan annelerin eğitim düzeyinin Türkiye ortalamasının altında ve hem sosyo-kültürel hem de sosyo-ekonomik açıdan daha düşük seviyede olduğunu düşündürmektedir.

Annelerin ilerleyen yaşlarıyla birlikte artan çocuk sayısıyla ilişkili olarak deneyimlerinin de artmasıyla ev kazalarına yönelik güvenlik önlemlerini tanılama düzeyleri yüksek olmaktadır $(2,11,24)$. Öztürk ve ark'nın (2) yaptıkları çalışmada genç annelerin ev kazalarını azaltmak için sürekli önlem alma konusunda yetersiz kaldıkları belirtilmiştir. Samsun'da 0-6 yaş grubu çocuğu olan 130 annenin alındığı çalışmada $\geq 40$ yaş annelerin diğer yaş gruplarına göre ev kazalarına yönelik güvenlik önlemlerini tanılama düzeylerinin yüksek olduğu saptanmış, bu durumun istatistiksel olarak anlamlı olmadığı $(p>0.05)$ görülmüştür (11). Çalışmamızda literatürle uyumlu olarak > 40 yaş olan annelerin diğer yaş gruplarındakine göre ölçekten daha yüksek puan aldıkları belirlenmiş, annelerin yaşları ile "Sıfır-Altı Yaş Grubu Çocuğu Olan Annelerin Ev Kazalarına Yönelik Güvenlik Önlemlerini Tanılama Ölçeği”nden aldıkları puan ortalamaları arasında anlamlı fark olmadığı ( $p$ $>0.05$ ) saptanmıştır (Tablo 2). Bu bulgu genç annelerin daha az çocuk sahibi olduklarından dolayı daha az deneyimli olabileceğini düşündürmektedir.

Öztürk ve ark.'nın (2) yaptıkları çalışmada eğitim seviyesi yüksek annelerin çocuklarının daha fazla ev kazalarına maruz kaldıkları sonucuna ulaşılmış; fakat yaralanmalarla sonuçlanan ev kazalarına yönelik müdahalelerde ise eğitim seviyesi yüksek annelerin daha etkili oldukları belirlenmiştir. Konya ilinde 0-6 yaş grubu çocuğu olan 150 annenin alındığı çalışmada ilköğretim mezunu annelerin ortaöğretim ve lisans mezunu annelere oranla ev kazalarına yönelik daha fazla güvenlik önlemi aldıkları görülmüş, annelerin ev kazalarına yönelik güvenlik 
önlemlerini almaları ile ilköğretim, ortaöğretim ve lisans mezunu olmaları arasında anlamlı farklılaşmanın $(p<0.001)$ olduğu belirlenmiştir (25). Başka bir çalışmada ise üniversite mezunu olan annelerin diğer eğitim seviyesine sahip annelere göre ev kazalarına yönelik güvenlik önlemlerini tanılama ölçeğinden aldıkları puan ortanca değerleri daha düşük saptanmış, fark istatistiksel olarak anlamlı $(p<$ 0.001) bulunmuştur (11). Bu bulguların yanında Atak ve ark.'nın (26) Balibey ve ark.'nın (27) ve Erkal'ın (28) yaptıkları araştırmalarda ebeveynlerin eğitim düzeyleri arttıkça ev kazalarına yönelik güvenlik önlemlerini tanılama düzeylerinin de arttığı görülmüştür. Bizim çalışmamızda ise üniversite mezunu annelerin ilköğretim ve lise mezunu olanlara göre daha düşük puan aldığı belirlenmiş, annelerin eğitim durumları ile "Sıfır-Altı Yaş Grubu Çocuğu Olan Annelerin Ev Kazalarına Yönelik Güvenlik Önlemlerini Tanılama Ölçeği"nden aldıkları puan ortalamaları arasında anlamlı fark olmadığı $(p>0.05)$ saptanmıştır (Tablo 2).

Literatürde çekirdek aile tipine sahip annelerin, ataerkil aile tipine sahip annelerden daha az ev kazalarına yönelik güvenlik önlemi aldığını bildiren çalışmalar olduğu gibi $(11,26)$, geniş aileye sahip annelerin bilgi ve ölçek puan ortalamalarının çekirdek aileye göre daha fazla olduğunu bildiren çalışmalar da yer almaktadır $(25,28)$. Ankara'da $0-5$ yaş grubu çocuğu olan 500 ailenin alındığı çalışmada ailede çocuk sayısının fazlalaşması, çocukların gecekonduda yaşaması ve geniş aileye sahip olması çocuklarda ev kazası geçirme riskini arttırdığı sonucuna ulaşılmıştır (29). Bizim çalışmamızda ise çekirdek aile tipine sahip olan annelerin geniş ve parçalanmış aile tipine sahip olanlara göre ölçekten aldıkları puanın daha yüksek olduğu belirlenmiş, evdeki çocuk sayısı $\geq 3$ olan annelerin diğerlerine göre ölçekten daha düşük puan aldıkları saptanmıştır. Aile tipi ile ölçek toplam puanları arasında istatistiksel olarak anlamlı fark ( $p<0.05$ ) bulunurken, evdeki çocuk sayısı ile ölçek toplam puanları arasında istatistiksel olarak anlamlı fark olmadığı ( $p>0.05$ ) belirlenmiştir (Tablo 2). Bu durum çocuk sayısı arttıkça evde beraber yaşayan kişi sayısının artacağını, çocuklara bakan kişinin dikkatinin dağılacağını dolayısıyla çocukların kaza geçirme riskinin de artacağını düşündürmektedir.

Malatya'da beş yaşın altında 704 çocuğun alındığı çalışmada sosyo-ekonomik düzeyi düşük ailelerin çocuklarının daha fazla ev kazası yaşadıkları ve ailelerinin de ev kazaları risklerini tanılama düzeylerinin düşük olduğu bildirilmiştir (26). Şahiner ve ark.'nın (30) yaptıkları çalışmada sosyo-ekonomik düzeyi düşük olan ailelerin ev kazaları geçirme oranının daha yüksek olduğu bildirilmiştir. Yalaki ve ark'nın (29) çalışmasında çocukluk çağı kazalarının kırsal, yarı-kentsel yerleşim bölgelerinde yüksek olduğu, Çiçekler ve ark.'nın (25) çalışmasında da ev kazalarındaki risklerin algılanmasında ailenin gelir düzeyinin başlıca etkenlerden biri olduğu belirtilmiştir. Bizim çalışmamızda literatürle uyumlu olarak ailenin gelir seviyesi ile ölçekten aldıkları toplam puan arasında istatistiksel olarak ileri düzeyde anlamlı fark $(p<0.001)$ bulunmuştur (Tablo 2). Bu bulgu ailenin gelirinin az olması çocuğun yaşadığı bölgede güvenlik önlemlerini almayı erteletebileceğini ve göz ardı edilebileceğini düşündürmektedir.

Özmen ve ark.'nın (24) yaptıkları çalışmada çocuğu ev kazası geçirmiş olan annelerin geçirmeyenlere göre "Sıfır-Altı Yaş Grubu Çocuğu Olan Annelerin Ev Kazalarına Yönelik Güvenlik Önlemlerini Tanılama Ölçeği"nden daha yüksek puan aldıkları belirlenmiştir. Aynı ölçeğin kullanıldığı Ankara'da 0-6 yaş grubu çocuğu olan 514 annenin alındığı çalışmada ölçekten yüksek puan alanların çocuğu ev kazası geçirenlerin olduğu görülmüştür (28). Turan ve Ceylan'ın (31) yaptıkları çalışmada ise çocukları kaza geçirmeyen annelerin (son bir yıl içerisinde) ölçekten daha yüksek puan aldıkları belirlenmiştir. Bizim çalışmamızda ise Özmen ve ark.'nın (24) ve Erkal'ın (28) çalışmasına benzer olduğu, çocuğun ev kazası geçirme durumu ile ölçekten aldıkları toplam puan arasında istatistiksel olarak ileri düzeyde anlamlı fark ( $p<0.001)$ olduğu bulunmuştur (Tablo 2). Çalışmalar arasındaki farklılıkların çalışma gruplarından kaynaklanabileceği düşünülmektedir. Bunun yanında bizim çalışmamızdaki bu bulgu çocukları daha önce kaza geçiren annelerin deneyim kazandıklarını dolayısıyla ölçekten daha yüksek puan aldıklarını düşündürmektedir. 
Ev ortamında küçük düzenlemelerin yapılması çocukların kazalara karşı korumalarını artırmaktadır (15). Ev ortamında güvenlik uygulamalarının alınması, çocuğun yakından takibi ebeveynlerin sorumluluğudur. Annelere gereksinimlerine göre interaktif şekilde kazaların önlenebileceğine dair eğitim ve eğitim sonrasında onların hatırlamalarını sağlayıcı konu ile ilgili broşür verilmesi ailelerin bu konu ile ilgili bilgi ve tutumlarını değiştireceği ve dolayısıyla çocuklarda kaza görülmesini azaltacağı bildirilmiştir (15-17). Çocukluk çağı ev kazalarını önlemek amacıyla King ve ark (5) tarafından yapılan çalışmada eğitim sonrası katılımcıların \% 63'ünde bilgi, tutum ve uygulamalarında değişim saptanmış ve bu değişimin istatistiksel olarak anlamlı olduğu ( $p=0.001$ ) belirlenmiştir. Altundağ ve Öztürk'ün (3) 1-3 yaş grubu çocuğu olan annelere ev kazalarına yönelik verdikleri eğitim sonrası "Ev Kazalarına Yönelik Güvenlik Önlemlerini Tanılama Ölçeği"nden alınan puan

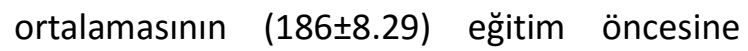
(158.98ะ14.48) göre artmış olduğu belirlenmiştir. Bizim çalışmamızda literatürle uyumlu olarak; annelerin "Sıfır-Altı Yaş Çocuklarda Annenin Ev Kazalarına Yönelik Güvenlik Önlemlerinin Tanılama Ölçeği" puan ortalamasının EÖ $(70.95 \pm 13.41)$ 'ne göre ES (151.72 \pm 61.67$)$ 'da artmış olduğu ve bu farkın istatistiksel olarak anlamlı olduğu $(p<0.001)$ görülmüştür (Şekil 1). Annelere verilen eğitimin interaktif şekilde verilmesi, eğitimde görsel eğitim ve broşür kullanılması annelerin eğitim sonrası bilgi puan ortalamasını artırdığını düşündürmektedir. Ayrıca annelere verilen eğitimler annelerin ev kazalarına karşı güvenlik önlemleri almalarına imkan sağladığından, çocukluk çağı kazalarını önlemede etkili bir yöntemdir $(5,15,32)$ ve çalışmada elde edilen bulgular da verilen eğitimin etkili olduğunu göstermektedir.

$\mathrm{Bu}$ araştırma anaokuluna devam eden ve ulaşılabilen, araştırma kapsamına alınan 0-6 yaş çocuğu olan 200 anneden elde edilen verilerle sınırlıdır. Çalışmamızda annelere verilen ev kazalarından korunmaya yönelik eğitimin, annelerin bilgi düzeyinde artışa neden olduğu gözönüne alınırsa; gelecekte yurt çapında çocukların kazalardan korunmasına yönelik aile eğitimlerini içeren kapsamlı çalışmaların yapılması gerektiği düşünülmektedir.

Sonuç olarak;

Araştırma sonucunda elde ettiğimiz bulgular; çocukları kaza geçiren annelerin bu kazalar sonucunda deneyim kazandıklarını ve annelere verilen ev kazalarından korunmaya yönelik eğitimin, annelerin bu konudaki bilgi düzeylerinde artışa neden olduğunu göstermektedir. Annelerin ev kazalarını önleyebilecekleri konusunda farkındalıklarının artırılması ve güvenli ev ortamı oluşturma konusunda kendilerine rehberlik edilmesi, kazalarla ilişkili riskleri ortadan kaldırmaya yönelik çalışmalar yapılması ve farklı eğitim yöntemleri kullanılarak yapılan eğitimin etkisini belirleyecek çalışmaların yapılması ve bu çalışmalarda hemşirelerin yer alması önerilmektedir.

\section{Çıkar Örtüşmesi}

Çalışmada hiçbir çıkar örtüşmesi bulunmamaktadır.

Teşekkür

Araştırma verilerinin toplanmasında yardımcı olan Koc EN, Tekdemir S, Kocatürk E. teşekkür ederiz.

\section{KAYNAKLAR}

1. World Health Organization-2015. Injuries. http://www.who.int/topics/injuries/en/ [Erişim Tarihi: 23 Mayıs 2015].

2. Öztürk C, Yıldırım Sarı H, Bektaş M, Elçigil A. Home accidents and mothers measurements in preschool children. Anatol J Clin Investig 2010;4(1):1521.

3. Altundağ S, Oztürk MC. The effects of home safety education on taking precautions and reducing the frequency of home accidents. Ulus Travma Acil Cerrahi Derg 2007;13(3):180-5.

4. Karakurt Ü, Satar S, Bilen A, Açıkalın A, Gülen $M$. Occupational accidents and emergency medicine. Eurasian J Emerg Med 2012;11:227-37.

5. King WJ, LeBlanc JC, Barrowman NJ, Klassen T, Bernard-Bonnin A, Robitaille $Y$, et al. Long term effects of a home visit to prevent childhood injury: three year follow up of a randomized trial. Inj Prev 2005;11(2):1069.

6. Uskun E, Alptekin F, Öztürk M, Kişioğlu AN. The attitudes and behaviors of housewives in the prevention of domestic accidents and their first aid knowledge levels. Ulus Travma Acil Cerrahi Derg 2008;14(1):46-52.

7. World Health Organization-2008. World report on child injury prevention, http://www.who.int/violence_injury_prevention/child/in jury/world_report/en/ [Erişim Tarihi: 15 Kasım 2015].

8. Yilmaz Kurt F, Aytekin A. Home accidents in children aged 0-6 years. Journal of Health Science and Profession-HSP 2015;2(1):22-32. 
9. Küçüktaş̧̧ K, Ergin $H$, Çırak B, Kıroğlu Y. Penetran meningoencephalitis and cerebro-spinal fluid fistula developing as a result of a house accident from a knitting needle. Ege J Med 2010;49(2):117-22.

10. Corrarino JE, Walsh PJ, Nadel E. Does teaching scald burn prevention to families of young children make a difference? A pilot study. J Pediatr Nurs 2001;16(4):256-62.

11. Tural Büyük $E$, Çavuşoğlu $F$, Teker E. Defining the security measures taken by mothers with zero to six years old children against home accidents. J DU Health Sci Inst 2015;5(3):17-22.

12. Inanç DÇ, Baysal SU, Coşgun L, Taviloğlu K, Ünüvar E. Underlying factors in childhood injuries. Turk Arch Ped 2008;43(4):84-8.

13. Lafta RK, Al-Shatari SA, Abass S. Mothers' knowledge of domestic accident prevention involving children in Baghdad City. Qatar Med J 2013;2013(2):50-6.

14. Dowd MD, Keenan HT, Bratton SL. Epidemiology and prevention of childhood injuries. Crit Care Med 2002;30(11):385-92.

15. Çelik S. Nursing role on prevention of Injury/accident to people with mental disability. Journal of Contemporary Medicine 2014;4(Supp):91-7.

16. Dereli F, Turasay N, Özçelik H. Determinations of the first aid-related knowledge levels of the mothers having children at the age of $0-6$ and who live in the Muğla number two health clinic district. TAF Prev Med Bull 2010;9(3):217-24.

17. Yıldırım Sarı H, Girli A. Accident and ınjury in children with developmental disabilities. Journal of Anatolia Nursing and Health Sciences 2012;15(4):283-8.

18. Çalışkan K, Avcı Ö, Acar V, Candan Dönmez Y. 06 yaş grubu çocuğu olan annelerin düşmelere ilişkin ilk yardım uygulamalarının incelenmesi. Maltepe Üniversitesi Hemşirelik Bilim ve Sanat Dergisi 2010;3(3):2-9.

19. Çınar ND, Görak G. 0-6 yaş çocuklarda annenin ev kazalarına yönelik güvenlik önlemlerini tanılama ölçeğinin geliştirilmesi, geçerlik ve güvenirlik çalışması. Çocuk Forumu 2003;6: 22-7.

20. Turan T, Altundağ DS, Yorgancı M, Yıldııım Z. The prevention of home accidents among children aged 0-6 years. Ulus Travma Acil Cerrahi Derg 2010;16(6):5527.

21. Kim HB, Kim DK, Kwak YH, Shin SD, Song KJ, Lee $\mathrm{SC}$ et al. Epidemiology of traumatic head injury in Korean children. J Korean Med Sci 2012;27(4):437-42.
22. Altuntaş $M$, Kaya $M$, Demir Ş, Oyman $G$, Metecan A, Rastgel $H$, et al. Determination of preventable accidents in children between the ages of 0 14 and taking measures associated with them. Smyrna Medical Journal 2013;1:28-33

23. Türkiye İstatistik Kurumu-2014. TÜiK, Toplumsal Cinsiyet istatistikleri. www.tuik.gov.tr/ [Erişim Tarihi: 15 Kasım 2015].

24. Özmen D, Ergin D, Şen N, Çetinkaya A. 0-6 yaş grubu çocuğu olan annenin ev kazalarına yönelik güvenlik önlemlerinin tanılanması. Aile ve Toplum 2007;9(3):1320.

25. Yıldız Çiçekler C, Konuk Er R, Alakoç Pirpir D, Büyükbayraktar Ç. 0-6 yaş grubunda çocuğu olan annelerin ev kazalarına yönelik güvenlik önlemlerinin çeşitli değişkenlere göre incelenmesi. Çukurova Üniversitesi Sosyal Bilimler Enstitüsü Dergisi 2012;21(3):157-74.

26. Atak N, Karaoğlu L, Korkmaz Y, Usubütün S. A household survey: unintentional injury frequency and related factors among children under five years in Malatya. The Turk J Pediatr 2010;52(3):285-93.

27. Balibey M, Polat S, Ertem I, Beyazova U, Şahin F. Çocukluk çağında ev kazalarına yol açan etmenler. Sürekli Tıp Eğitimi Dergisi. 2011;20(3):89-97.

28. Erkal S. Identification of the number of home accidents per year involving children in the 0-6 age group and the measures taken by mothers to prevent home accidents. Turk J Pediatr 2010;52(2):150-7.

29. Yalaki Z, Taşar MA, Kara N, Dallar Y. Measuring the awareness of home injuries in families with a low socioeconomic status. The Journal of Academic Emergency Medicine 2010; 9:129-33.

30. Şahiner P, Özkan Ö, Hamzaoğlu O. The incidence and risk factors of the home accidents in the households with low socioeconomic level in Kocaeli. TAF Prev Med Bull. 2011;10(3): 257-68.

31. Turan T, Ceylan SS. 0-6 Yaş grubu çocukları olan annelerin ev kazalarını önlemek için aldıkları güvenlik önlemlerinin aile özelliklerine ve son bir aydaki ev kazaları sıklığına göre değerlendirilmesi. Sağlık ve Toplum 2007;17(4):52-8.

32. Posner JC, Hawkins LA, Garcia-Espana F, Durbin DR. A randomized, clinical trial of a home safety intervention based in an emergency department setting. Pediatrics 2004;113(6):1603-8. 